\title{
CONCERNING PH GRADIENTS BETWEEN THE EXTRACELLULAR COMPARTMENT AND FLUIDS BATHING THE BONE MINERAL SURFACE AND THEIR RELATION TO CALCIUM ION DISTRIBUTION *
}

\author{
By STEIN SCHARTUM † AND GEORGE NICHOLS, JR.‡ \\ (From the Departments of Medicine and Biochemistry, Harvard Medical School, \\ Boston, Mass.)
}

(Submitted for publication June 19, 1961 ; accepted January 25, 1962)

In a previous report describing studies of surviving bone samples in vitro it was shown that various aspects of bone cell metabolism have an influence on the calcium concentrations achieved in the incubation medium after a steady state is reached (1). Although the $\mathrm{Ca}$ and $\mathrm{Ca} \times \mathrm{P}$ concentrations maintained in the media surrounding actively metabolizing bone samples were higher than those maintained by inactivated samples, the underlying mechanisms remained obscure.

Since normal serum is supersaturated with $\mathrm{Ca}$ and $\mathrm{P}$ with respect to bone mineral and at the same time must be considered to be in diffusion equilibrium with this phase, it has been postulated that the composition of serum differs from the fluid which is in direct contact with the bone mineral (2-5). At low $\mathrm{pH}$, bone mineral solubility is increased. Therefore several workers (2-5) have suggested that, if a $\mathrm{pH}$ difference could be shown to exist between the fluid bathing the bone mineral and the circulating fluids, an explanation would be provided for the apparently increased solubility of bone salt in vivo. The existence of a $\mathrm{pH}$ at the mineral surface below that of serum has been suggested by histochemical studies carried out by Cretin (6), but the relationship of this gradient to cellular metabolism and its significance in the mobilization of $\mathrm{Ca}$ and $\mathrm{P}$ from the bone has not been directly investigated, partly, at least, because of the inherent difficulty of measuring serially the $\mathrm{pH}$ of the microscopic layer of fluid in contact with the mineral in living bone. However, an

* This work was supported by Grant no. A-854 (C4) and (C5) from the Institute of Arthritis and Metabolic Diseases, National Institutes of Health, United States Public Health Service.

$\dagger$ Research Associate in Medicine. Present address: Gjövik Fylessykehus, Gjövik, Norway.

$\ddagger$ Markle Scholar in Medical Science. alternative, albeit indirect, approach to this problem seemed possible using the same type of in vitro system employed in previous studies (1).

It was argued that, if bone samples were incubated in media of sufficiently low $\mathrm{pH}$, it was reasonable to presume that any $\mathrm{pH}$ gradient sustained by cellular activity in living samples would be abolished. This would be the result, in living samples, of raising the $\mathrm{H}^{+}$ion concentration in the ambient medium to or above that at the mineral surface, while in heated samples any $\mathrm{pH}$ gradient created by cellular activity would be abolished also, but by another mechanism (in this case, cell (eath). Thus, if the creation and maintenance of $\mathrm{H} \mathrm{H}^{+}$gradient were the mechanism by which cellular activity created the difference in steady state $\mathrm{Ca}$ and $\mathrm{Ca} \times \mathrm{P}$ concentration products between living and heat-inactivated samples, this difference should disappear as the final $\mathrm{pH}$ of the ambient medium decreased, even though the total concentrations of these ions increased. ${ }^{1}$ Obviously two factors were critical in such experiments: first, bone cells had to be capable of normal metabolic activity although incubated at low $\mathrm{pH}$; second, rates of ion exchange and solubility of bone mineral must not be altered by the heating procedure. Previous experience (unpublished preliminary experiments) indicating that cells would metabolize normally at $\mathrm{pH} 6.6$, and evidence already published that heating did not change diffusion from bone samples (1), made such an approach seem feasible.

Our experience with such a system is reported below. The results obtained support the view that the maintenance by cellular activity of a $\mathrm{H}^{+}$

1 Such an increase in total concentrations after incubation at low $\mathrm{pH}$ was anticipated on the basis of preliminary observations in this laboratory and in others $(2,4,5)$. 


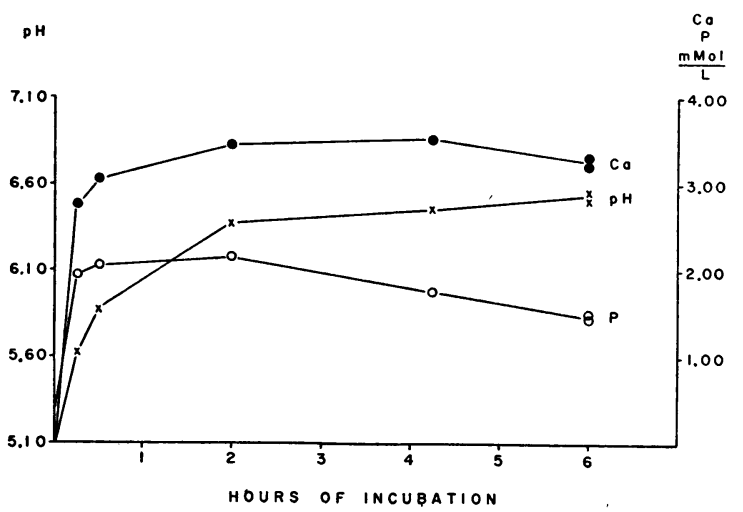

Fig. 1. Plot of values of $\mathrm{PH}, \mathrm{CA}$ and $\mathrm{P}$ concentraTIONS IN THE MEDIA WITH INCREASING TIME OF INCUBATION, TAKEN FROM A TYPICAL EXPERIMENT. The values at each time represent those found in a single incubation flask, with the exception of the 6-hour point, where two flasks were analyzed. The data for both are given to illustrate the reproducibility of the system.

gradient between the fluid bathing the mineral surface and the ambient medium is a major factor in determining the distribution of $\mathrm{Ca}$ and perhaps of $\mathrm{P}$ between bone samples and their surrounding fluids in vitro. By analogy, the concept that a similar mechanism exists in vivo is given added support.

\section{METHODS}

Preparation of bone samples (calvaria from young adult male white Swiss mice), heat-inactivation, analytical techniques for determination of $\mathrm{Ca}, \mathrm{P}$, and lactate, and statistical methods were as previously described (1). $\mathrm{pH}$ in the media was determined by glass electrode using a Beckman $\mathrm{pH}$ meter, model $\mathrm{G}$.

The bone samples were incubated aerobically in a Dubnoff metabolic incubator at $37.8^{\circ} \mathrm{C}$ for 6 hours in 2 $\mathrm{ml}$ of modified Krebs-Ringer medium ${ }^{2}$ buffered with Walpole's acetate buffer. Glucose and antibiotics were added to the medium as in previous experiments. The composition of the buffer was varied from one experiment to another in order to obtain the different $\mathrm{pH}$ 's required. No attempt was made to correct for the small variations in molarity.

Because of the great affinity of bone mineral for $\mathrm{H}$ ions, the $\mathrm{pH}$ of the medium rose during incubation, despite the presence of buffer. Therefore, in order to obtain a given final $\mathrm{pH}$ in the medium, the initial $\mathrm{pH}$ had to be considerably lower. In Figure 1 values for $\mathrm{pH}$, together with $\mathrm{Ca}$ and $\mathrm{P}$ concentrations obtained at different times of incubation of living samples in a typical experiment, are plotted to illustrate this point. As can be seen, dur-

2 The medium contained no $\mathrm{Ca} ; \mathrm{P}$ was present at a concentration of 0.40 mmoles per $\mathrm{L}$. ing the first period of incubation $\mathrm{pH}$ values rose rapidly, and thereafter slowly. At the initial low $\mathrm{pH}$ such large amounts of $\mathrm{Ca}$ and $\mathrm{P}$ were released into the medium that this had become supersaturated with these ions at the $\mathrm{pH}$ reached after 2 hours (5). At the end of 6 hours the medium was still supersaturated, and $\mathrm{Ca}$ and $\mathrm{P}$ concentrations were decreasing as these ions were again deposited on the bone mineral.

These observations indicate two points. First, ions are able to pass from extracellular fluid to bone mineral and vice versa at rates seemingly proportional to the size of the concentration gradient. Second, a steady state distribution of $\mathrm{Ca}$ and $\mathrm{P}$ between bone sample and medium was not achieved despite 6 hours' incubation because of the continuing slow change of $\mathrm{pH}$. Even when much longer periods of incubation (which might impair the viability of bone cells) were used, a steady state was not achieved for the same reason. However, in contrast to previous experiments, the establishment of steady state conditions was not critical for the purposes of these experiments, and indeed the use of a supersaturated system as the endpoint might be considered desirable, since in vivo the circulating fluids are also supersaturated.

In each experiment equal numbers of normal and heatinactivated bone samples were incubated at the same time. Lactate production was used to determine cell viability and rate of metabolism as outlined previously (1). In the present studies lactate production by the experimental, surviving samples was compared to the amount of lactate produced by normal bones incubated in Krebs-Ringer bicarbonate media $(\mathrm{pH} \mathrm{7.4)}$ at the same time. In addition, after the initial incubation, these two groups of samples were transferred to freshly prepared bicarbonate media and incubated once more. Thus, an estimate could be obtained, first, of the depression of metabolism that might occur during incubation at low $\mathrm{pH}$ and, second, of the viability of the cells at the end of this incubation.

\section{RESULTS}

1. Ca and $P$ concentrations in the media: Differences between surviving and heat-inactivated bones at different final $p H$ in the medium. Final $\mathrm{pH}$ and concentrations of $\mathrm{Ca}$ and $\mathrm{P}$ in the media surrounding both living and heat-inactivated samples are shown in the first two sets of columns in Table I. As was expected from previous reports $(2,4,5)$, the highest concentrations of both $\mathrm{Ca}$ and $P$ in the media surrounding both types of samples were observed at the lowest final $\mathrm{pH}$. Variations in the absolute values obtained in different experiments were such that a precise inverse relationship between these variables at each $\mathrm{pH}$ was not demonstrable.

The important point in relation to the hypothesis under consideration was the difference between 
the concentrations of these ions supported by living and heat-inactivated samples at each $\mathrm{pH}$. These differences are shown in the right-hand columns of Table I. From these data it is apparent that, while the differences in Ca concentrations at a final medium $\mathrm{pH}$ of 7.10 were appreciable $(0.40$ mmoles per $\mathrm{L}, \mathrm{p}<0.001)$, they gradually disappeared as $\mathrm{pH}$ decreased. At $\mathrm{pH} 6.54$ or lower, no reproducible differences in final concentration were found. In experiment $\mathrm{N} 6$, representing an intermediate $\mathrm{pH}$ range, the individual values for inactivated samples were $1.81,1.83$, 1.87 , and 1.90 , while for living samples the values were $2.01,2.05,2.08$, and 1.79 . This last value is considerably below the range of the rest of the group, perhaps because of cell death in this particular sample. Had this value been omitted, the difference would have been statistically significant even at this $\mathrm{pH}$.

No consistent differences in total $\mathrm{P}$ concentrations between living and dead samples were found with changes in $\mathrm{pH}$. Therefore, $\mathrm{Ca} \times \mathrm{P}$ concentration products changed with changes in the final $\mathrm{Ca}$ concentration. In all experiments $\mathrm{Ca} \times \mathrm{P}$ ion products $^{3}$ were in excess of those predicted for

${ }^{3}$ Calculated as $[\mathrm{Ca}]^{3} \times[\mathrm{P}]^{2}$, expressed as milligrams per $100 \mathrm{ml}$. the $\mathrm{pH}$ value from data on the solubility of dry bone powder (5).

It was important to compare mean final $\mathrm{pH}$ values in the medium for living and inactivated samples because the possibility existed that differences in final $\mathrm{Ca}$ concentration, where present, might have been the result of a lower $\mathrm{pH}$ in the medium surrounding living samples. No consistent difference in final medium $\mathrm{pH}$ was found between living and heat-inactivated samples at each $\mathrm{pH}$ level. Media surrounding living samples had final $\mathrm{pH}$ 's which were sometimes above and sometimes below those of inactive samples. These differences were not correlated in any way with differences in final $\mathrm{Ca}$ concentration.

2. Cellular metabolism in surviving bone during and at the end of incubation. As was pointed out above, it was of critical importance to know whether the disappearance of a difference in $\mathrm{Ca}$ concentration in the medium between living and heat-inactivated samples at low $\mathrm{pH}$ was due to impairment of cellular metabolism. For this reason the accumulation of lactate in the medium over 6 hours was measured in each incubation flask and compared with that of controls. These data are shown in the first column of Table II.

It is apparent that the accumulation of lactate

TABLE I

Final $p H$ and concentrations of $C a$ and $P$ in media surrounding normal and heat-inactivated bone samples

\begin{tabular}{|c|c|c|c|c|c|c|c|c|c|c|}
\hline \multirow{2}{*}{\multicolumn{2}{|c|}{ Expt. }} & & \multicolumn{3}{|c|}{ Normal } & \multicolumn{3}{|c|}{ Heat-inactivated } & \multirow[b]{2}{*}{$\Delta \mathrm{Ca}$} & \multirow[b]{2}{*}{$\Delta \mathrm{P}$} \\
\hline & & & $\underset{\mathrm{pH}}{\text { Final }}$ & $\mathrm{Ca}$ & $\mathbf{P}$ & $\underset{\mathrm{pH}}{\text { Final }}$ & $\mathrm{Ca}$ & $\mathbf{P}$ & & \\
\hline & & & \multicolumn{3}{|c|}{ mmoles $/ L$} & & \multicolumn{2}{|c|}{ mmoles $/ L$} & \multicolumn{2}{|c|}{ mmoles $/ L$} \\
\hline \multicolumn{2}{|c|}{ N 20} & $\begin{array}{l}\text { Mean } \\
\text { SD* } \\
\text { No. } \dagger\end{array}$ & $\begin{array}{l}7.10 \\
0.14 \\
6\end{array}$ & $\begin{array}{l}2.78 \\
0.06 \\
6\end{array}$ & $\begin{array}{l}0.74 \\
0.03 \\
6\end{array}$ & $\begin{array}{l}7.14 \\
0.09 \\
6\end{array}$ & $\begin{array}{l}2.38 \\
0.03 \\
6\end{array}$ & $\begin{array}{l}0.72 \\
0.01 \\
6\end{array}$ & 0.40 & 0.02 \\
\hline $\mathrm{N}$ & 5 & $\begin{array}{l}\text { Mean } \\
\text { SD } \\
\text { No. }\end{array}$ & $\begin{array}{l}7.05 \\
0.05 \\
2\end{array}$ & $\begin{array}{l}2.31 \\
0.09 \\
2\end{array}$ & $\begin{array}{l}1.07 \\
0.10 \\
2\end{array}$ & $\begin{array}{l}7.03 \\
0.07 \\
2\end{array}$ & $\begin{array}{l}2.11 \\
0.08 \\
2\end{array}$ & $\begin{array}{l}1.10 \\
0.03 \\
2\end{array}$ & 0.20 & -0.03 \\
\hline $\mathrm{N}$ & 6 & $\begin{array}{l}\text { Mean } \\
\text { SD } \\
\text { No. }\end{array}$ & $\begin{array}{l}6.98 \\
0.11 \\
4\end{array}$ & $\begin{array}{l}1.98 \\
0.13 \\
4\end{array}$ & $\begin{array}{l}0.95 \\
0.02 \\
4\end{array}$ & $\begin{array}{l}6.87 \\
0.04 \\
4\end{array}$ & $\begin{array}{l}1.85 \\
0.04 \\
4\end{array}$ & $\begin{array}{l}0.91 \\
0.02 \\
4\end{array}$ & 0.13 & 0.04 \\
\hline & 7 & $\begin{array}{l}\text { Mean } \\
\text { SD } \\
\text { No. }\end{array}$ & $\begin{array}{l}6.54 \\
0.04 \\
6\end{array}$ & $\begin{array}{l}2.64 \\
0.09 \\
6\end{array}$ & $\begin{array}{l}1.19 \\
0.08 \\
6\end{array}$ & $\begin{array}{l}6.45 \\
0.05 \\
6\end{array}$ & $\begin{array}{l}2.64 \\
0.04 \\
6\end{array}$ & $\begin{array}{l}1.21 \\
0.03 \\
6\end{array}$ & 0.00 & -0.02 \\
\hline & 2 & $\begin{array}{l}\text { Mean } \\
\text { SD } \\
\text { No. }\end{array}$ & $\begin{array}{l}6.52 \\
0.08 \\
4\end{array}$ & $\begin{array}{l}2.87 \\
0.08 \\
4\end{array}$ & $\begin{array}{l}1.37 \\
0.04 \\
4\end{array}$ & $\begin{array}{l}6.47 \\
0.03 \\
4\end{array}$ & $\begin{array}{l}2.83 \\
0.08 \\
4\end{array}$ & $\begin{array}{l}1.39 \\
0.05 \\
4\end{array}$ & 0.04 & -0.02 \\
\hline & 8 & $\begin{array}{l}\text { Mean } \\
\text { SD } \\
\text { No. }\end{array}$ & $\begin{array}{l}6.19 \\
0.03 \\
5\end{array}$ & $\begin{array}{l}4.00 \\
0.06 \\
5\end{array}$ & $\begin{array}{l}1.87 \\
0.11 \\
5\end{array}$ & $\begin{array}{l}6.28 \\
0.11 \\
5\end{array}$ & $\begin{array}{l}3.97 \\
0.15 \\
5\end{array}$ & $\begin{array}{l}1.85 \\
0.14 \\
5\end{array}$ & 0.03 & 0.02 \\
\hline
\end{tabular}

* $\mathrm{SD}=$ standard deviation of the mean.

$\dagger$ No. $=$ number of incubations. 
TABLE II

Lactate production during and after incubation at different medium $p H$ 's

\begin{tabular}{|c|c|c|}
\hline & \multicolumn{2}{|c|}{ Lactate production* } \\
\hline & $\begin{array}{c}\text { Initial } \\
\text { incubation }\end{array}$ & $\begin{array}{l}\text { Subsequent } \\
\text { incubation }\end{array}$ \\
\hline $\begin{array}{c}\text { Controls } \\
\text { Mean } \dagger \\
\text { No. } \ddagger \\
\text { SD }\end{array}$ & $\begin{array}{r}100 \\
4 \\
10\end{array}$ & $\begin{array}{r}100 \\
4 \\
24\end{array}$ \\
\hline $\begin{array}{c}\text { pH§ } 5.52-7.05 \\
\text { Mean } \\
\text { No. } \\
\text { SD }\end{array}$ & $\begin{array}{r}57 \\
4 \\
20\end{array}$ & $\begin{array}{r}52 \\
4 \\
9\end{array}$ \\
\hline $\begin{array}{c}\text { Controls } \\
\text { Mean } \\
\text { No. } \\
\text { SD }\end{array}$ & $\begin{array}{r}100 \\
4 \\
15\end{array}$ & $\begin{array}{r}100 \\
4 \\
10\end{array}$ \\
\hline $\begin{array}{ll}\text { pH } & 5.33-6.98 \\
\text { Mean } \\
\text { No. } \\
\text { SD }\end{array}$ & $\begin{array}{r}64 \\
4 \\
17\end{array}$ & $\begin{array}{r}74 \\
3 \\
15\end{array}$ \\
\hline $\begin{array}{c}\text { Controls } \\
\text { Mean } \\
\text { No. } \\
\text { SD }\end{array}$ & $\begin{array}{r}100 \\
2 \\
4\end{array}$ & $\begin{array}{r}100 \\
2 \\
31\end{array}$ \\
\hline $\begin{array}{ll}\text { pH } & 5.10-6.54 \\
\text { Mean } \\
\text { No. } \\
\text { SD }\end{array}$ & $\begin{array}{r}81 \\
2 \\
6\end{array}$ & $\begin{array}{r}105 \\
2 \\
8\end{array}$ \\
\hline $\begin{array}{c}\text { Controls } \\
\text { Mean } \\
\text { No. } \\
\text { SD }\end{array}$ & $\begin{array}{r}100 \\
4 \\
8\end{array}$ & $\begin{array}{r}100 \\
4 \\
7\end{array}$ \\
\hline $\begin{array}{ll}\mathrm{pH} & 5.05-6.52 \\
& \text { Mean } \\
\text { No. } & \\
\text { SD }\end{array}$ & $\begin{array}{r}70 \\
4 \\
14\end{array}$ & $\begin{array}{r}54 \\
4 \\
15\end{array}$ \\
\hline
\end{tabular}

* Expressed as per cent of lactate production by controls incubated at $\mathrm{pH} 7.4$ at the same time. All control and subsequent incubations were in bicarbonate buffer. Initial incubation of experimental samples was in acetate buffer.

$\dagger$ Number of determinations.

$\ddagger$ Standard deviation.

\& Initial and final $\mathrm{pH}$ in initial incubation.

in media surrounding surviving bone samples was between 60 and 80 per cent of the "normal" amount (measured in bicarbonate buffer) over the whole $\mathrm{pH}$ range studied. ${ }^{4}$ The rate of lactate production, if anything, was higher in those samples incubated in the lower range of $\mathrm{pH}$ where no

4 This degree of reduction in the rate of lactate production was observed in previous experiments (7) when phosphate was substituted for bicarbonate buffer. It seems likely therefore to be related to the nature of the buffer used rather than to the $\mathrm{pH}$ per se. differences in $\mathrm{Ca}$ concentration were observed. Thus, the presence of a low $\mathrm{pH}$ in the medium did not appear to inhibit cellular metabolism, at least as measured by the rate of production of its chief acid end product, lactate.

Although the average lactate production, as shown, was the same over the $\mathrm{pH}$ range studied, cellular metabolism and acid production at the end of the incubation period might have been slowing down in the samples in the "lower $\mathrm{pH}$ range." To test for this possibility, samples were reincubated in media at $\mathrm{pH} 7.4$ as indicated above. Unfortunately, the lactate values for this group during the subsequent incubation at $\mathrm{pH} 7.4$ showed a considerable spread (see Table II). However, the mean values for the samples in the "lower range" were again higher, indicating that the viability of these samples was at least equal to those in which the final $\mathrm{pH}$ had been 7 or above.

\section{DISCUSSION}

The data presented above indicate that the ability of living bone samples to support a Ca concentration in their surrounding media higher than that maintained by heat-inactivated samples is abolished when the $\mathrm{pH}$ of the surrounding medium

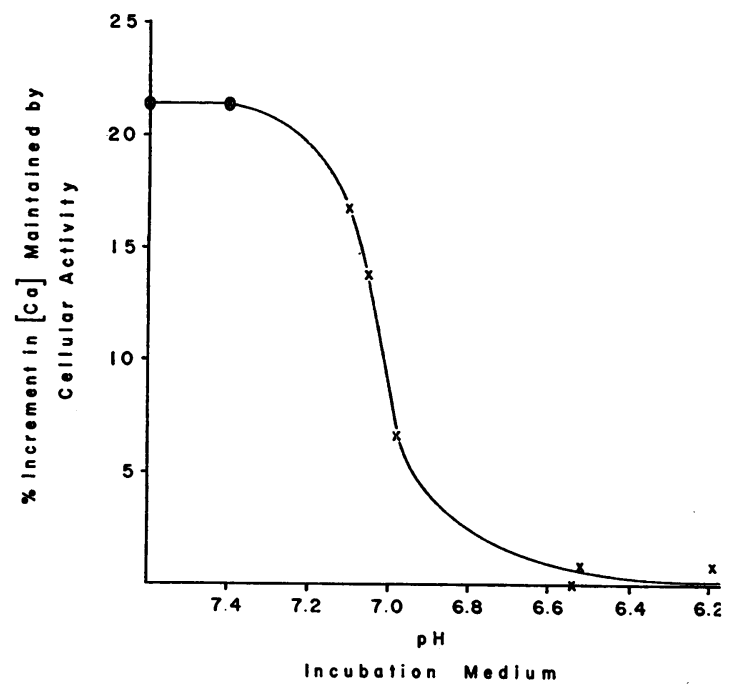

Fig. 2. Percentage increments in Ca concentraTION IN THE MEDIA MAINTAINED BY NORMAL COMPARED TO HEAT-INACTIVATED BONES AT DIFFERENT FINAL MEDIUM pH's. $\mathrm{pH}$ values used in this plot were those for incubations utilizing living samples. $\times=$ Points calculated from data in Table I; $\otimes=$ points calculated from data previously published from this laboratory (1). 
is lowered. This phenomenon occurs despite the fact that the ability of such living samples to produce their chief acid end product, lactate, is not impaired. This observation is consistent with the view that the differences in $\mathrm{Ca}$ concentration in the medium between surviving and inactivated samples incubated at medium $\mathrm{pH}$ 's of 7.1 and above are the result of a $\mathrm{pH}$ gradient between the fluid bathing the crystal surface and the medium which is maintained by cellular metabolism.

Nordin has suggested, on the basis of the solubility of bone powder in vitro, that were the $\mathrm{pH}$ of the fluid in contact with the bone mineral surface between 6.6 and 6.8 , the $\mathrm{Ca} \times \mathrm{P}$ ion product in the extracellular fluid would be explained (4). These findings suggest that, in the system used in these and previous experiments, differences in $\mathrm{Ca}$ concentration of the medium should approach a maximum at a medium $\mathrm{pH}$ of 7.4 or above and a minimum at $\mathrm{pH}$ values of 6.6 or below, if the differences are indeed the result of a $\mathrm{pH}$ gradient maintained by cell activity. Differences at $\mathrm{pH}$ values between 7.4 and 6.6 might be expected to fall along a sigmoid curve with its steepest part centered around a $\mathrm{pH}$ of 7 .

Figure 2 has been prepared to examine how well data currently available fit this prediction. Differences in medium $\mathrm{Ca}$ concentration between living and heat-inactivated samples, expressed as per cent of the inactive sample concentration, have been plotted against final medium $\mathrm{pH}^{5}$ The values at $\mathrm{pH} 7.4$ were taken from a previous communication (1), while the others have been calculated from Table I. The data fit the prediction quite well except that the steepest part of the curve is slightly to the left of its predicted position. However, it should be noted that the $\mathrm{pH}$ values recorded are those at the end of the incubation period and the mean $\mathrm{pH}$ during the incubation was actually lower (Figure 1). It is also of interest that data taken from experiments in which a steady state distribution of $\mathrm{Ca}$ was reached (values at medium $\mathrm{pH} 7.4$ to 7.6 ) fit on a curve described by experiments in which the medium was always supersaturated with $\mathrm{Ca}$ and $\mathrm{P}$. This finding suggests that either type of system can be used to examine this phenomenon with equal

5 Expression of values in this manner eliminates differences due to daily experimental variation and the greater solubility of bone mineral at lower $\mathrm{pH}$. validity. Finally, a possible explanation for the lack of correlation of $\mathrm{Ca}$ concentration observed at steady state with variations in medium $\mathrm{pH}$ between 7.6 and 7.4 (1) is supplied, since in that $\mathrm{pH}$ range differences in $\mathrm{Ca}$ concentration are maximal and small changes in $\mathrm{pH}$ should have little measurable effect.

The lack of differences seen in total $\mathrm{P}$ concentrations in the medium in this study and in most of the previous experiments (1) is of interest, since these results also may suggest the mechanism for the cellular metabolic effects. As has been mentioned (1), these results might be expected on the basis of MacGregor and Nordin's work (5) if the underlying mechanism were acid production. An explanation for the increased $\mathrm{Ca} / \mathrm{P}$ ratio in the medium when bone salt is being solubilized by an acid may be that $\mathrm{H}$ ions displace $\mathrm{Ca}$ ions from the surface, as suggested by Neuman (3). In addition, phosphate and $\mathrm{H}^{+}$must be removed from the medium if the reaction: $1 \mathrm{Ca}_{3}\left(\mathrm{PO}_{4}\right)_{2}+3 \mathrm{H}^{+}+1 \mathrm{PO}_{4} \rightleftarrows 3 \mathrm{CaHPO}_{4} \rightleftarrows$ $3 \mathrm{Ca}^{++}+3 \mathrm{HPO}_{4}=$ is to proceed to the right. Thus both phenomena would tend to increase the $\mathrm{Ca} / \mathrm{P}$ ratios in the medium.

Despite the correlation of these observations with predictions made on Nordin's data, and the concept of a local $\mathrm{pH}$ gradient maintained by cellular activity between the fluid at the bone mineral surface and the ambient medium, it must be emphasized that the proof of such a thesis is not yet available. While lactate production was not critically changed at low $\mathrm{pH}$, other aspects of cellular metabolism, not examined so far, could have been greatly modified. That other cellular activities, besides lactate production, are important in the maintenance of higher $\mathrm{Ca}$ concentrations by living samples has been indicated in previous work (1). Thus the possibility exists that some aspect (as yet unmeasured) of cellular metabolic activity, critical to $\mathrm{Ca}$ mobilization, was abolished by incubation at low $\mathrm{pH}$.

Just how such a $\mathrm{H}^{+}$gradient between bone mineral and extracellular fluid can be related to the high levels of $\mathrm{Ca}$ maintained in the medium by bone samples from parathyroid-treated animals (1) is also not yet clear. The increased passive solubility of the bone mineral, the increased $\mathrm{Ca} / \mathrm{P}$ ratio, and the increased rates of lactate (1) and citrate $(7,8)$ release into the medium from living 
samples taken from animals pretreated with this hormone, certainly fit with the concept that the rate at which bone cells produce acid is involved in this phenomenon. On the other hand, the lack of correlation between levels of lactate (1) and citrate $(8)$ in the medium and levels of $\mathrm{Ca}$ and $\mathrm{P}$ achieved under steady state conditions, and the similarity in the size of the fraction of total steady state $\mathrm{Ca}$ concentration which can be related to cellular activity between bone from normal and parathyroid-treated animals (1) argue against increases in the magnitude of the $\mathrm{H}^{+}$gradient being the critical factor. The explanation for these apparently conflicting pieces of evidence must await further work.

\section{SUM MARY}

1. Surviving and heat-inactivated bone samples (mouse calvaria) were incubated in vitro in media of different $\mathrm{pH}$, and $\mathrm{Ca}$ and $\mathrm{P}$ concentrations in the media were measured.

2. The ability of actively metabolizing bone samples to maintain higher $\mathrm{Ca}$ concentrations in their surrounding media than inactivated samples was abolished when $\mathrm{pH}$ in the media was decreased from about 7 to 6.5. This occurred while cellular metabolism continued at the same rate, as judged from lactate production. $\mathrm{P}$ concentrations were the same for both groups.

3. These findings are consistent with the view that cellular metabolic effects on $\mathrm{Ca}$ concentration in the medium are mediated, at least in part, through $\mathrm{pH}$ gradients between the bone fluid compartment and the medium.

4. By analogy, the results support the concept that the existence of a $\mathrm{pH}$ gradient between a fluid phase in bone and the circulating fluids is a factor underlying the apparent supersaturation of normal serum with respect to bone mineral.

\section{REFERENCES}

1. Schartum, S., and Nichols, G., Jr. Calcium metabolism of bone in vitro. Influence of bone cellular metabolism and parathyroid hormone. J. clin. Invest. 1961, 40, 2083.

2. Neuman, W. F., and Neuman, M. W. The Chemical Dynamics of Bone Mineral. Chicago, University of Chicago Press, 1958.

3. Neuman, W. F. The mechanism of parathyroid function. Lancet 1958, 78, 190.

4. Nordin, B. E. C. The solubility of powdered bone. J. biol. Chem. 1957, 227, 551.

5. MacGregor, J., and Nordin, B. E. C. Equilibration studies with human bone powder. J. biol. Chem. 1960, 235, 1215.

6. Cretin, A. Contribution histochemique à l'étude de la construction et de la destruction osseuse. Presse méd. 1951, 59, 1240.

7. Borle, A. B., Nichols, N., and Nichols, G., Jr. Metabolic studies of bone in vitro. I. Normal bone. J. biol. Chem. 1960, 235, 1206.

8. Vaes, G., and Nichols, G., Jr. Metabolic studies of bone in vitro. III. Citric acid metabolism and bone mineral solubility. Effects of parathyroid hormone and estradiol. J. biol. Chem. 1961, 236, 3323. 